\title{
Chemical effects of macroalgae on larval settlement of the broadcast spawning coral Acropora millepora
}

\author{
Chico L. Birrell ${ }^{1}$, Laurence J. McCook ${ }^{2,3, *}$, Bette L. Willis ${ }^{1,3}$, Lindsay Harrington ${ }^{1}$ \\ ${ }^{1}$ School of Marine and Tropical Biology, James Cook University, Townsville, Queensland 4811, Australia \\ ${ }^{2}$ Great Barrier Reef Marine Park Authority, PO Box 1379, Townsville, Queensland 4810, Australia \\ ${ }^{3}$ ARC Centre of Excellence for Coral Reef Studies, James Cook University, Townsville, Queensland 4811, Australia
}

\begin{abstract}
Recovery of degraded reefs is dependent on the settlement of coral larvae into habitats typically dominated by benthic algae, so that benthic algae may play pivotal roles in coral settlement and reef recovery. Here we demonstrate that waterborne influences of macroalgae could affect coral settlement before larvae contact reef substrata and that such effects vary between macroalgae. We tested for waterborne effects of algae on both pre-settlement behaviour and settlement of larvae of the coral Acropora millepora onto live fragments of the crustose coralline alga Hydrolithon reinboldii. Treatments comprised seawater collected from aquaria that had previously contained 1 of 3 macroalgae common on degraded reefs. The foliose brown macroalga, Lobophora variegata, enhanced coral settlement by $40 \%$ relative to substratum control treatments. In contrast, the filamentous green macroalga Chlorodesmis fastigiata ('turtle weed'), hindered coral settlement by delaying settlement of larvae, although final settlement was similar to that in control treatments. Padina sp., a foliose brown macroalga closely related to $L$. variegata, reduced coral settlement by $30 \%$ compared with substratum controls. The demonstration of waterborne effects suggests that macroalgae can influence coral settlement before larvae reach reef substrata, even on a crustose coralline alga known to induce settlement, and even where the immediate settlement location is free of macroalgal cover. These results demonstrate the complexity in the mechanisms underlying the effects that overabundant macroalgal growth may have on reef recovery. These effects have critical implications for the ecological resilience of coral reefs, especially as climate change increases the frequency and severity of disturbances to reefs.
\end{abstract}

KEY WORDS: Coral $\cdot$ Macroalgae $\cdot$ Recruitment $\cdot$ Resilience $\cdot$ Settlement $\cdot$ Allelopathy

\section{INTRODUCTION}

Globally, degradation of coral reefs is increasingly generating algal dominated environments (Hughes et al. 2003, 2005), particularly as climate change increases the frequency of reef decline. The ecological resilience of reefs relies on the ability of corals to recruit or recover successfully in environments dominated by various forms of benthic algae (Diaz-Pulido \& McCook 2002, Hughes et al. 2007, McCook et al. 2007). The period during which larvae settle and metamorphose is a critical but vulnerable stage in the early life history of corals, linking the processes of dispersal and larval supply to the survival and growth of benthic juveniles. Successful settlement depends on how coral larvae respond to and are affected by influences from the physical environment and benthic biota (Harrison \& Wallace 1990, Pawlik 1992, Abelson \& Denny 1997, Birrell et al. 2008). Since fleshy or turfing algae invariably dominate degraded and disturbed coral reefs, they potentially exert a controlling influence on coral settlement, which may restrict reef recovery and significantly undermine the ecological resilience of these reefs (Done 1992, Hughes 1994, Connell 1997, 
McCook 1999, McCook et al. 2001, 2007, Hughes et al. 2007, review by Birrell et al. 2008). In addition to the physical pre-emption of space and changes to the character of settlement surfaces through processes such as sediment trapping (Birrell et al. 2005), benthic algae also contribute significantly to the chemical environment confronting larvae during the settlement process (Jensen 1977, Amsler et al. 1992, McCook et al. 2001, Birrell et al. 2008). However, the potential for macroalgae to affect settlement of coral larvae through allelochemical processes has received little attention (Maypa \& Raymundo 2004, Kuffner et al. 2006, review by Birrell et al. 2008).

Emerging evidence indicates that a range of benthic algae can have chemical effects, which either enhance (Morse 1991, 1992, Pawlik 1992, Hadfield \& Paul 2001) or deter the settlement of marine invertebrate larvae (Steinberg et al. 2001, 2002, Walters et al. 2003, review by Birrell et al. 2008). Besides producing or harbouring secondary metabolites that can have direct effects on larvae (Steinberg \& de Nys 2002, Gross 2003, Walters et al. 2003), benthic algae may chemically alter the settlement environment, for example by modifying the seawater $\mathrm{pH}$ (McConnaughey et al. 2000) or by altering dissolved nutrient concentrations as a result of metabolic processes such as photosynthesis, respiration and calcification (Carpenter et al. 1991, Larkum et al. 2003). Such chemical changes may affect habitat selection and settlement by coral larvae, which display chemotaxis or orientate in response to chemical gradients (Harrison \& Wallace 1990, Pawlik 1992).

Such algal effects on coral larvae and the environment larvae encounter are undoubtedly important to reef resilience, but demonstrations of macroalgal effects on coral replenishment processes are scarce (McCook et al. 2007, Birrell et al. 2008). Recent studies have demonstrated that effects of algae and cyanobacteria on invertebrate larvae, including corals, can range from settlement cues and inducers to lethal antifouling compounds, and also have shown that the outcomes of macroalgal chemical interactions with larvae vary among taxa (e.g. Walters et al. 1996, Baird \& Morse 2004, Kuffner \& Paul 2004, Maypa \& Raymundo 2004, Kuffner et al. 2006, review by Birrell et al. 2008).

However, much of the previous work has focused on coral species with brooding planulae (and limited dispersal) or has considered settlement onto artificial (e.g. glass, terracotta) or unidentified substrata (e.g. assemblages of different crustose coralline algae), thereby confounding effects of algae with effects of settlement substrata, or has focused on effects of chemicals bound to algal surfaces (e.g. chemicals bound to crustose coralline algae on which corals may settle) (Morse et al. 1988, 1994, 1996, Pawlik 1992, Maypa \& Raymundo 2004, Kuffner et al. 2006, reviewed in Birrell et al.
2008). Steinberg et al. (2001) and Steinberg \& de Nys (2002) highlight the potential for water-soluble chemicals from macroalgae to signal sites for invertebrate settlement, suggesting that inducers of larval settlement are most likely to be primary metabolites (e.g. polysaccharides, amino acids, peptides) because these are typically present in higher concentrations than are secondary metabolites and are readily exuded or leaked from macroalgae into seawater.

This study explored the effects of water-soluble chemicals released from benthic macroalgae on the settlement of larvae from the coral, Acropora millepora (Ehrenberg). Specifically, we investigated water-borne effects of 3 common macroalgae, Lobophora variegata (Lamouroux), Padina sp. and Chlorodesmis fastigiata (C. Agardh 'turtle weed'), on pre-settlement behaviour and larval metamorphosis in the presence of a crustose coralline alga, Hydrolithon reinboldii Weber-van Bosse \& Foslie, known to induce settlement of Acropora larvae (Morse et al. 1988, 1994, 1996). The macroalgae tested are common and widespread, especially on degraded reefs (Done 1992, Hughes 1994, McCook 1999). Importantly, we investigated settlement to a standardised substratum that was more likely to represent natural settlement substrata on reefs, than on artificial or unrealistic substrata.

\section{MATERIALS AND METHODS}

Experimental approach and design. To investigate potential water-soluble chemical effects of macroalgae on coral settlement, coral larvae were placed in seawater collected from aquaria that had contained either 1 of 3 algae or control treatments. Larvae of the coral Acropora millepora were produced and raised in aquarium facilities at Lizard Island Research Station using established procedures (Babcock \& Heyward 1986, Willis et al. 1997) and presented with live surfaces of the crustose coralline alga Hydrolithon reinboldii for settlement.

The experimental design tested 5 levels of seawater treatment: (1 to 3 ) seawater collected from tanks holding one of the macroalgae Lobophora variegata, Chlorodesmis fastigiata, or Padina sp.; (4) seawater collected from a tank holding pieces of reef substrata (substratum control); and (5) plain seawater control. Each level of treatment was replicated in 10 petri dishes, with each petri dish containing a piece of Hydrolithon reinboldii. Treatments were randomly assigned to petri dishes.

Experimental treatments and procedures. To create the different seawater treatments, live, whole and intact thalli of Lobophora variegata, Chlorodesmis fastigiata and Padina sp. were placed in tanks of still 
seawater under shaded natural light. For each treatment, 61 of seawater were conditioned for $90 \mathrm{~min}$ with $250 \mathrm{~g}$ ( $\pm 25 \mathrm{~g}$ wet weight) of each macroalga. This treatment was chosen to approximate macroalgal density and water residence within macroalgal assemblages on an inshore or degraded reef habitat. Macroalgae, chosen to have minimal epiphytes or fouling organisms, were collected from fringing reefs surrounding Lizard Island $\left(14^{\circ} 41^{\prime} \mathrm{S}, 145^{\circ} 28^{\prime} \mathrm{E}\right)$ on the Australian Great Barrier Reef. Importantly, to avoid the release of injury-activated stress compounds into seawater treatments, macroalgae were maintained intact, attached to pieces of substratum, during collection and experimental procedures, and any damaged specimens were discarded. Because macroalgae remained attached to substratum, a reef substratum treatment was included to control for potential influences from biofilms or other microbiota associated with the substratum. To create the substratum control, pieces of reef substratum similar to those used in the algal treatments were treated in the same manner as for the algal treatments (approximately $100 \pm 10 \mathrm{~g}$ wet weight of reef substratum). Substratum pieces (with or without algae) were stabilised for approximately $20 \mathrm{~h}$ to minimise and standardise any effects of boring organisms, but were used within $24 \mathrm{~h}$ to avoid degeneration of the algae. To control for the potential presence of waterborne chemicals in seawater used in the experimental treatments, a final 'seawater control' treatment used plain seawater with no algal or substratum addition.

Assays for waterborne algal effects on larval settlement were replicated in 10 plastic petri dishes, each containing $40 \mathrm{ml}$ of the appropriate seawater treatment, a live fragment of Hydrolithon reinboldii, and 20 competent coral larvae. Larval development and settlement competency were assessed microscopically prior to the experiment using random subsamples of larvae at daily intervals after fertilisation (see Willis et al. 1997 for fertilisation protocols). Colonies of Hydrolithon reinboldii were collected from fringing reefs surrounding Lizard Island within $24 \mathrm{~h}$ of the experiment and fragmented into pieces of equal surface area $\left(1.0 \pm 0.1 \mathrm{~cm}^{2}\right)$ with approximately equal volumes of attached substratum $\left(0.5 \pm 0.05 \mathrm{~cm}^{3}\right)$. Coral larvae were counted as they were added to petri dishes using a glass pipette. Replicates were maintained at a constant temperature of $26^{\circ} \mathrm{C}$ with moderate levels of natural light.

Data and analysis. As the primary response variable, the number of coral larvae that settled and metamorphosed on Hydrolithon reinboldii surfaces was recorded after $48 \mathrm{~h}$, and expressed as a percentage of the 20 larvae added to each replicate. These observations were made using a stereo dissection microscope and accounted for all 20 larvae originally placed in each petri dish. These observations confirmed that, of those that settled, larvae exclusively settled on live $H$. reinboldii surfaces and not on the petri dish or surfaces attached to $H$. reinboldii fragments. Data analysis of treatment effects on coral settlement involved a 1-way ANOVA followed by a priori comparisons of algal treatments with substratum controls. Data were tested for homogeneity of variance using Cochran's C-test, and for normality of residuals graphically and for kurtosis and skewness (Systat 8.0 ${ }^{\mathrm{TM}}$ ).

As secondary response variables, 3 measures of larval behaviour were used: (1) substratum testing, for activities in which larvae touched surfaces with their aboral end repeatedly and occasionally attached, but without necessarily metamorphosing; (2) swimming, for visibly motile larvae; and (3) stressed, for larvae observed to be motionless or floating at the water surface, presumably including dead larvae (Harrison \& Wallace 1990, Raimondi \& Morse 2000). The percentage of larvae expressing each category of behaviour was recorded when initially added to each petri dish, and 2, 10 and 24 h later. Larval behaviour was observed using a magnifying glass to avoid moving the petri dishes and disturbing either settled or unsettled larvae. Data are presented for substratum testing and stressed behaviours only, as results for swimming closely mirrored those for substratum testing; data are presented graphically and are not analysed statistically owing to the confounding effects of nonindependence between the 3 behavioural measures, and between repeated measures on the same samples.

\section{RESULTS}

\section{Effects of water-soluble influences on coral settlement}

Mean settlement of Acropora millepora larvae was nearly 1.4 times greater in seawater that had been collected from tanks containing the macroalgae Lobophora variegata (mean $\pm \mathrm{SE}, 76 \pm 4.6 \%$ of larvae settled) than in the substratum control treatment (55 \pm $6.0 \%$ settled), and about twice that in the unconditioned seawater control $(37 \pm 4.6 \%$ settled; Fig. 1, Table 1). In contrast, larval settlement in seawater collected from tanks holding the closely related alga Padina sp. $(39 \pm 6.7 \%)$, was nearly one-third less than in the substratum control. Final settlement in the Chlorodesmis fastigiata treatment $(46 \pm 4.6 \%)$ was slightly, but not significantly, less than in the substratum control (Table 1). Interestingly, larval settlement in the seawater control treatment $(37 \pm 4.6 \%)$ was the least of all treatments, and markedly less than in the substratum control treatment. 


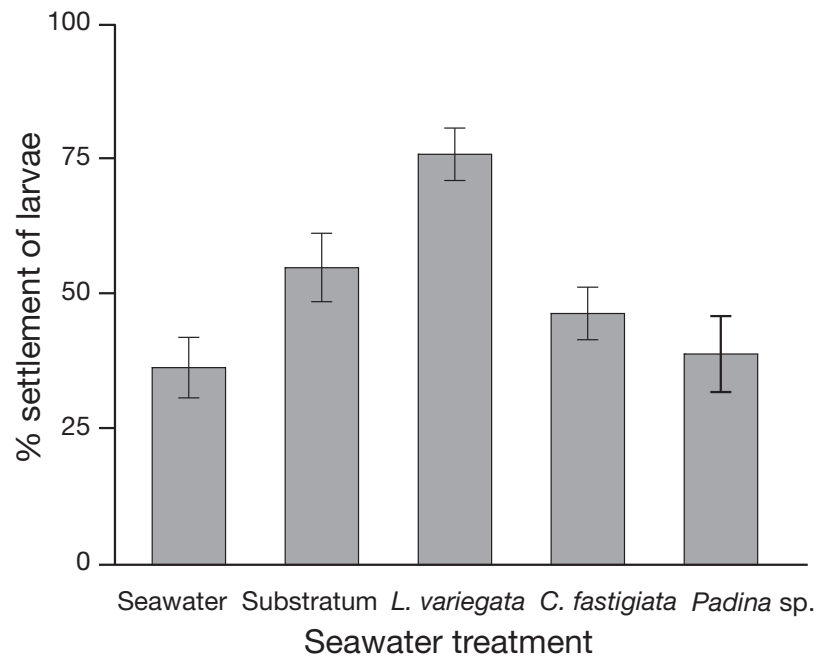

Fig. 1. Acropora millepora. Mean percentage ( $\pm 1 \mathrm{SE})$ of larvae from the coral $A$. millepora settled on live surfaces of the crustose coralline algae Hydrolithon reinboldii after $48 \mathrm{~h}$ in seawater and substratum controls and macroalgal treatments (Lobophora variegata, Chlorodesmis fastigiata, Padina sp.). Means for each treatment are calculated from 10 repli-cates, which each contained 20 coral larvae

\section{Effects of water-soluble influences on larval behaviour}

There was a dramatic difference in initial behaviour of coral larvae when added to the different treatments (Fig. 2). In all but one treatment, namely Chlorodesmis fastigiata, most larvae immediately began testing the coralline algal substrata, and continued to do so for
Table 1. Results of ANOVA tests comparing the effects of waterborne influences of macroalgae on larval settlement (Acropora millepora) among the macroalgal treatments (Lobophora variegata, Chlorodesmis fastigiata, Padina sp.) and controls (substratum and seawater). Cochran's $C$-test indicates homogeneity of variance $(C$ critical value $=0.307$ ). Data are not transformed

\begin{tabular}{|lrcrc|}
\hline Source of variation & df & MS & $F$ & p \\
\hline Treatment & 4 & 101.47 & 8.434 & $<0.001$ \\
Error & 45 & 12.031 & & \\
Cochran's $C=0.295$ & & & \\
A priori comparisons with substratum control & \\
L. variegata & & 0.010 \\
C. fastigiata & & 0.279 \\
Padina sp. & & 0.045 \\
Seawater control & & 0.021 \\
\hline
\end{tabular}

$24 \mathrm{~h}$, and very few larvae appeared stressed throughout this period. In contrast, in the C. fastigiata treatment, almost no Acropora millepora larvae were observed to display substratum testing behaviour at the start of treatment $(2.5 \pm 1.3 \%)$ and most appeared stressed. However, within $2 \mathrm{~h}$, the mean percentage of larvae testing substrata in this treatment increased by over 20 -fold (to $71 \pm 3.8 \%$ ) and subsequently remained approximately constant (65 to $70 \%$ ) for the first $24 \mathrm{~h}$. Nonetheless, consistently fewer larvae (by 10 to $15 \%$ ) were observed to test substrata after 2, 10 and $24 \mathrm{~h}$ in the C. fastigiata treatment compared with other treatments.

Compared with other treatments, larvae in the Lobophora variegata treatment showed consistently

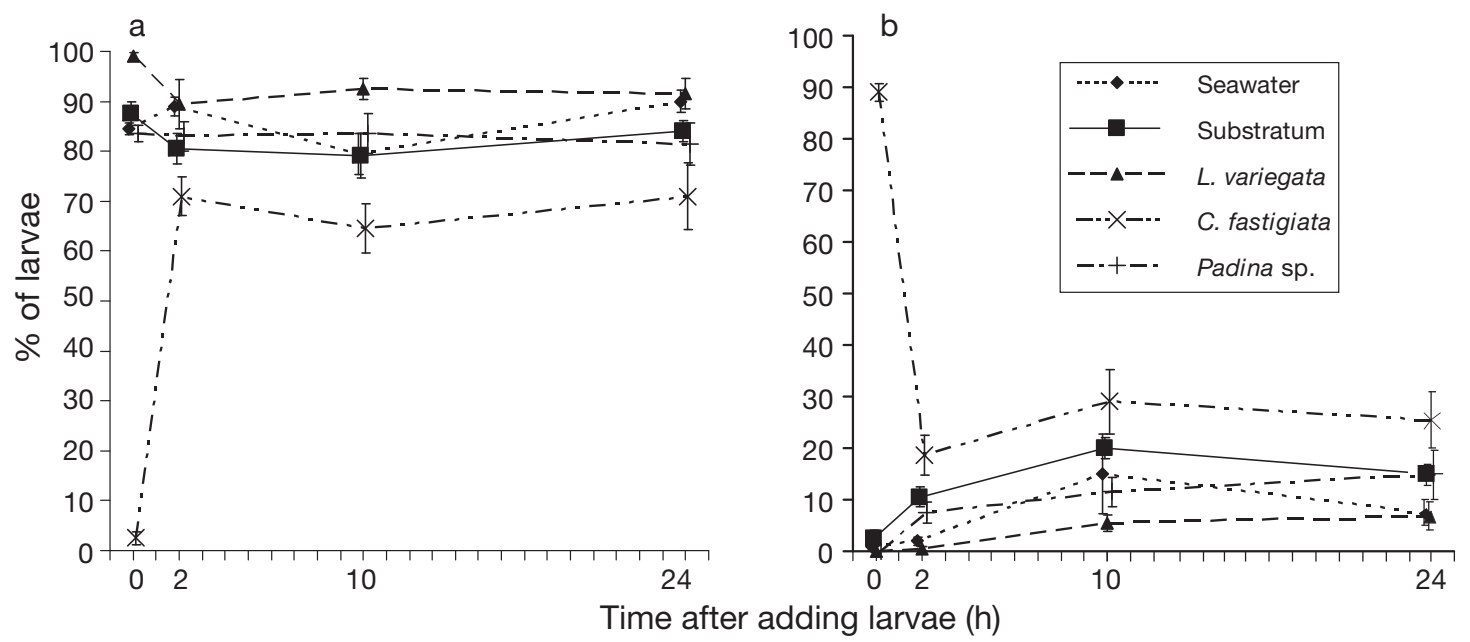

Fig. 2. Acropora millepora. Mean percentage ( $\pm 1 \mathrm{SE}$ ) of $A$. millepora larvae displaying the behavioural responses defined as (a) testing substratum and (b) stressed, in seawater and substratum controls and macroalgal treatments (Lobophora variegata, Chlorodesmis fastigiata, Padina sp.). Means for each treatment are calculated from 10 replicates, which each contained 20 coral larvae. The response of larvae in C. fastigiata treatments is unlikely to promote settlement in the vicinity of this macroalgae 
higher levels of substratum testing (initially $99 \pm$ $0.7 \%$ ), and lower levels of stressed behaviour. Larval behaviour in the Padina sp. treatment was generally similar to that in the 2 control treatments, with around 75 to $85 \%$ of larvae testing substrata throughout the $24 \mathrm{~h}$ of observation.

\section{DISCUSSION}

The results of this study are significant to understanding recruitment and recovery of corals on degraded reefs for several reasons. Firstly, they demonstrate that some macroalgae may influence the settlement of coral larvae by means of water-soluble chemical influences, the first such demonstration for a broadcast spawning coral. On Indo-Pacific reefs, recruitment is dominated by broadcast spawning corals (e.g. Hughes et al. 1999) and recruitment of spawning corals on degraded, algal dominated reefs requires dispersal through algal beds. In contrast, the larvae of brooding corals are released into the benthic boundary layer and are negatively buoyant, keeping them close to suitable substrata and sites for settlement (Harrison \& Wallace 1990). This highlights an overlooked mechanism of coral-algae interaction with serious implications for coral recruitment on disturbed or degraded reefs.

Secondly, the results demonstrate that different species of macroalgae can have markedly different waterborne effects on the behaviour and settlement of Acropora millepora larvae. Water from the foliose brown macroalga Lobophora variegata enhanced coral settlement by approximately $40 \%$ relative to the substratum control treatment. In contrast, settlement was inhibited by water from the closely related Padina sp., and the filamentous green macroalga Chlorodesmis fastigiata delayed settlement responses of larvae. Although final settlement in the $C$. fastigiata treatment was not significantly different from the control treatment, in nature such delays may reduce the likelihood of coral larvae settling in the vicinity.

Thirdly, demonstrations of waterborne effects on coral settlement suggest that macroalgae potentially affect coral settlement before larvae reach reef substrata, even if the immediate settlement area is free of macroalgal cover. In particular, macroalgae may affect coral replenishment beyond the immediate spatial scale of the physical space occupied by algae to surrounding and down-current areas, and coral replenishment may be affected in reef areas even if there is relatively low macroalgal cover and sufficient favourable settlement surfaces. The extent of these effects will vary considerably, depending on factors such as the amount of algae and dilution due to condi- tions such as turbulence and currents. There is a need for further research on the extent of algal chemical effects in different natural conditions (i.e. reefs dominated by fleshy algae or turfing and crustose forms). However, it seems likely that large beds of fleshy algae will have the most significant effects.

Fourthly, the results demonstrate that waterborne influences from macroalgae affect the settlement of corals even on a substratum considered to be important for inducing coral settlement in the field. For example the crustose coralline algae Hydrolithon reinboldii is known to induce settlement of larvae from a variety of corals, particularly acroporids, and has a widespread distribution on the Great Barrier Reef (Morse et al. 1996, Harrington 2004, Harrington et al. 2004, R. Steneck \& L. Harrington unpubl. data). Thus, coral settlement may be affected by the combination of different benthic macroalgae present in an assemblage (e.g. both fleshy and crustose algae) and not solely by the calcareous red algae reported to induce coral settlement (e.g. Morse et al. 1988, 1996, Heyward \& Negri 1999). Interestingly, Nugues \& Szmant (2006) showed that larvae of Favia fragrum settled on the green alga Halimeda opuntia even when another substratum more suitable for settlement was present, although they suggested this may result from high abundance of larvae. In contrast, all settled larvae settled on the coralline algae in our study.

\section{Chemical effects of macroalgae on settlement}

In general, the settlement, behaviour and survival of coral larvae are known to be influenced by chemical and physical properties of the marine environment (Harrison \& Wallace 1990, Pawlik 1992, Maida et al. 1995a,b, Raimondi \& Morse 2000), and algae are known to release a range of chemicals into the surrounding water (Amsler et al. 1992, Walters et al. 2003), so it is not surprising that macroalgae affect coral settlement through waterborne chemical effects. Only recently, however, has there been evidence for such effects from macroalgae or benthic cyanobacteria. Kuffner \& Paul (2004) reported allelopathic reduction of larval survival of the broadcast spawning coral Acropora surculosa and recruitment of the brooding coral Pocillopora damicornis in response to the cyanobacterium Lyngbya majuscula. Kuffner et al. (2006) found reduced overall recruitment, or settlement at distance, for the brooding coral Porites astreoides in response to the macroalgae Dictyota pulchella and Lobophora variegata, as well as the cyanobacteria L. majuscula, $L$. polychroa and L. confervoides. Water-soluble chemicals released by Sargassum polycystum killed all unsettled Pocillopora damicornis larvae within $24 \mathrm{~h}$ and all 
settled larvae within 10 d (Maypa \& Raymundo 2004). Similarly, all unsettled larvae died within $24 \mathrm{~h}$ in Laurencia papillosa treatments, whereas larvae that did settle displayed $100 \%$ survival. Halimeda opuntia and Peyssonnelia rubra had no deleterious effects on settled or unsettled larvae (Maypa \& Raymundo 2004). In contrast to our results, Baird \& Morse (2004) report reduced survival of larvae of both the brooding corals, Stylophora pistillata and Acropora palifera, in response to treatments containing fragments of a Lobophora sp.

More generally, macroalgal influences on the chemistry of seawater (Amsler et al. 1992, Walters et al. 2003), include primary and secondary metabolites (Steinberg et al. 2001), pH (McConnaughey et al. 2000), and nutrient and organic carbon levels (Carpenter et al. 1991, Larkum et al. 2003, Kline et al. 2006, review by Birrell et al. 2008). Macroalgae have both surface-bound and waterborne chemical effects on the larval settlement of other invertebrates, including both deterrence and induction (Pawlik 1992, Steinberg et al. 2001, 2002, Steinberg \& de Nys 2002, Walters et al. 2003). For example, on Hawaiian coral reefs, the release of water-soluble chemicals by some macroalgal species (Ulva sp. and Sphacelaria sp.) inhibited settlement, and others (Dictyota spp.) even killed larvae of the fouling bryozoan Brugula neritina and the polychaete Hydroides elegans. In contrast, water-soluble chemicals released by Padina sp. enhanced settlement of $H$. elegans, whereas Sargassum spp. had no effect on B. neritina larvae (Walters et al. 1996).

Although our results provide clear evidence that macroalgae affected coral settlement through waterborne chemicals, the nature of the chemical influences is unclear. Compounds known to induce invertebrate larvae to settle are generally primary metabolites such as carbohydrates, peptides or even nutrients and are commonly water soluble, whereas deterrents are usually secondary metabolites that are insoluble (Steinberg et al. 2001). There is limited information available on chemical effects of the algae used in our experiment. Chlorodesmis fastigiata is known to produce a cytotoxic diterpenoid, chlorodesmin, a secondary metabolite that deters herbivores (Wylie \& Paul 1988, Hay et al. 1989, Paul et al. 1990). Lobophora variegata produces a variety of secondary metabolites, such as phlorotannins (Stern et al. 1996, Arnold \& Targett 1998, 2000) and bromophenols (Chung et al. 2003), which may deter herbivores, along with other chemicals (e.g. orcinol, phloroglucinol, salicylic acid, usnic acid; Walters et al. 2003 and references therein). Seawater passing over Lobophora variegata attracted Diadema antillarum (Solandt \& Campbell 2001), which feeds preferentially on the macroalga (Tuya et al. 2001). Padina has also been reported to contain secondary metabolites (e.g. alginic acid) with herbivore deterrent and cytotoxic capacity (Renaud et al. 1990, Walters et al. 1996, Ktari \& Guyot 1999, Chung et al. 2003, Walters et al. 2003). However, even closely related macroalgal taxa may contain different chemical compounds and have different chemical effects on the settlement of invertebrate larvae (Steinberg et al. 2001, 2002, Steinberg \& de Nys 2002, Walters et al. 2003).

It is also possible that bacteria, microflora or ephiphytes associated with the surfaces of the macroalgae contribute to the observed effects, although algal samples were chosen to minimise epiphytes. There is evidence that the induction of invertebrate settlement by calcareous and coralline algae is at least partially mediated by bacteria associated with the algae (Johnson et al. 1991, 1997, Morse \& Morse 1991, Johnson \& Sutton 1994, Negri et al. 2001, Harder et al. 2002, Webster et al. 2004). The surfaces of Lobophora variegata support diverse bacterial communities (Jensen et al. 1996), which may produce biologically active compounds capable of affecting invertebrates (Jiang et al. 1999). Distinguishing between allelochemical effects of macroalgae and those from associated organisms warrants further research.

\section{Implications for reef resilience}

The enhancement of coral settlement by Lobophora variegata is of particular interest for 2 reasons. Firstly, this macroalga is particularly widespread on disturbed and degraded reefs around the world, including the recent massive overgrowth of bleached corals in the southern Great Barrier Reef (Diaz-Pulido \& Diaz 1997, McClanahan et al. 2001, L. J. McCook unpubl. data). Secondly, there is an emerging body of evidence showing contrasting effects of Lobophora spp. on corals, and the current study emphasises that a particular species of alga may have different effects on different life history stages or demographic processes. Consistent with the positive effects found in the present study, are the promotion of first stage elongation of larvae from 7 acroporid corals (Morse et al. 1996) and the results of a survey of benthic biota surrounding coral recruits on inshore reefs of the Great Barrier Reef (Birrell 2003), which found L. variegata was more frequently present and more abundant in close proximity to coral recruits than in background communities. However, in contrast to these positive effects, Kuffner et al. (2006) reported avoidance of $L$. variegata by larvae of Porites astreoides and Baird \& Morse (2004) reported deleterious effects on coral larvae by Lobophora sp., although they also noted that injury to the algae tissue may have stimulated release of stress compounds. Several reports have shown that $L$. variegata 
actively competes with corals, overgrowing and killing both recruits and mature colonies (De Ruyter van Stevenick et al. 1988, Hughes 1994, Littler \& Littler 1997, Jompa \& McCook 2002a,b, Nugues \& Bak 2006, authors' pers. obs.), although the corals also defend themselves. It remains unclear to what extent these variable results reflect experimental differences, or biological, geographic or other variations (e.g. Paul et al. 2001), but it seems probable that, overall, reef overgrowth by L. variegata has detrimental effects on coral populations.

The implications of these small-scale experimental results for processes on reefs at large are also limited by several additional factors. In this experiment, larvae were tested over very small scales $(10 \mathrm{~cm})$ and were confined to relatively small areas (petri dishes), and so had limited options for settlement. In nature, coral larvae actively search the reef benthos before settling and can delay settlement to maximise the chance of finding a suitable microhabitat (Harrison \& Wallace 1990, Pawlik 1992, Raimondi \& Morse 2000). However, if larvae fail to encounter suitable microhabitats, evidence exists that they can metamorphose in suboptimal conditions, even without a surface to settle on (reviewed in Harrison \& Wallace 1990), and inhibition of invertebrate settlement by algal secondary metabolites may decrease as larvae mature (Gribben et al. 2006 for the algae Delisea pulchra and Dilophus marginatus). Thus, more coral larvae may have settled under the deleterious effects of Chlorodesmis fastigiata in this experiment than would settle close to the macroalga in nature, because they lacked alternative microhabitats in the experimental treatments. This could explain the reversal of larval behaviour in the Chlorodesmis treatment. Secondly, there was no water circulation in experimental treatments, whereas water flow and hydrodynamics in nature can disperse, dilute and mix different waterborne chemicals (Pawlik 1992, Maida et al. 1994, 1995a,b, Abelson \& Denny 1997). Thus, chemical conditions in this experiment are likely to have been more homogenous than under natural conditions and the effects more consistent. It is likely that algal effects may operate differently between microhabitat scales on the order of centimetres and larger scales that are relevant to reef-wide algal dominance. The use of experimental systems incorporating flow dynamics would help to bridge this gap.

\section{Summary}

In summary, this study demonstrates that macroalgae can influence larval settlement of a broadcast spawning coral by means of waterborne chemical effects, and that such effects vary considerably among algal taxa and include both enhancement and inhibition of larval settlement. This emphasises an overlooked effect of benthic algae on coral recruitment that is particularly relevant to disturbed or degraded reefs typically dominated by benthic macroalgae. The results suggest that abundant fleshy macroalgae could affect coral settlement before larvae reach the reef substratum, even on surfaces of a crustose coralline alga known to induce coral settlement, and even where the immediate settlement area is free of macroalgal cover. Thus, the nature of algal cover on reefs may have complex and previously unrecognized effects on coral recruitment, and, hence, on the recovery of coral assemblages following disturbance. As human effects, especially mass bleaching of corals due to climate change, become more frequent, large-scale algal dominance of reefs will also become more frequent (Diaz-Pulido et al. 2007), making such chemical effects potentially critical to the long-term resilience of coral reefs.

Acknowledgements. We gratefully acknowledge A. Negri, A. Heyward for comments on experimental procedures and G. Suosarri for assistance with raising larvae. We are thankful to the Lizard Island Research Station and its staff for providing facilities and support. Funding was contributed by the Cooperative Research Centre for the Great Barrier Reef World Heritage Area (CRC Reef), the Australian Institute of Marine Science (AIMS), a Great Barrier Reef Marine Park Authority student augmentative grant to C.L.B., an International Postgraduate Research Scholarship Award from James Cook University to L.H., the Australian Research Council to B.L.W. and C.L.B., and the Pew Fellowship Program in Marine Conservation to L.J.M. and C.L.B.

\section{LITERATURE CITED}

Abelson A, Denny M (1997) Settlement of marine organisms in flow. Annu Rev Ecol Syst 28:317-339

Amsler CD, Reed DC, Neushul M (1992) The microclimate inhabited by macroalgal propagules. Br Phycol J 27: 253-270

Arnold TM, Targett NM (1998) Quantifying in situ rates of phlorotannin synthesis and polymerization in marine brown algae. J Chem Ecol 24:577-595

Arnold TM, Targett NM (2000) Evidence for metabolic turnover of polyphenolics in tropical brown algae. J Chem Ecol 26:1393-1410

> Babcock RC, Heyward AJ (1986) Larval development of certain gamete-spawning scleractinian corals. Coral Reefs 5: 111-116

Baird AH, Morse ANC (2004) Induction of metamorphosis in larvae of the brooding corals Acropora palifera and Stylophora pistillata. Mar Freshw Res 55:469-472

Birrell CL (2003) Influences of benthic algae on coral settlement and post-settlement survival: implications for the recovery of disturbed and degraded reefs. MS thesis, James Cook University, Townsville

Birrell CL, McCook LJ, Willis BL (2005) Effects of algal turfs and sediment on coral settlement. Mar Pollut Bull 51: 408-414 
Birrell CL, McCook LJ, Willis BL, Diaz-Pulido G (2008) Effects of benthic algae on the replenishment of corals and the implications for the resilience of coral reefs. Oceanogr Mar Biol Annu Rev: 46:25-64

Carpenter RC, Hackney JM, Adey WH (1991) Measurements of primary productivity and nitrogenase activity of coral reef algae in a chamber incorporating oscillatory flow. Limnol Oceanogr 36:40-49

Chung HY, Ma WCJ, Ang PO, Kim JS, Chen F (2003) Seasonal variations of bromophenols in brown algae (Padina arborescens, Sargassum siliquastrum, and Lobophora variegata) collected in Hong Kong. J Agric Food Chem 51: 2619-2624

- Connell JH (1997) Disturbance and recovery of coral assemblages. Coral Reefs 16:S101-S113

> De Ruyter van Steveninck ED, Van Mulekom LL, Breeman AM (1988) Growth inhibition of Lobophora variegata (Lamouroux) Womersley by scleractinian corals. J Exp Mar Biol Ecol 115:169-178

Diaz-Pulido G, Diaz JM (1997) Algal assemblages in lagoonal reefs of Caribbean oceanic atolls. Proc 8th Int Coral Reef Symp, Panama, p 827-832

> Diaz-Pulido G, McCook LJ (2002) The fate of bleached corals: patterns and dynamics of algal recruitment. Mar Ecol Prog Ser 232:115-128

Diaz-Pulido G, McCook LJ, Larkum AWD, Lotze HK and others (2007) Vulnerability of macroalgae of the Great Barrier Reef to climate change. In: Marshall P, Johnson J (eds) Climate change and the Great Barrier Reef. Great Barrier Reef Marine Park Authority, Townsville, p 153-192

> Done TJ (1992) Phase-shifts in coral reef communities and their ecological significance. Hydrobiologia 247:121-132

Gribben PE, Marshall DJ, Steinberg PD (2006) Less inhibited with age? Larval age modifies responses to natural settlement inhibitors. Biofouling 22:101-106

Gross EM (2003) Allelopathy of aquatic autotrophs. Crit Rev Plant Sci 22:313-339

Hadfield MG, Paul VJ (2001) Natural chemical cues for settlement and metamorphosis of marine-invertebrate larvae. In: McClintock JB, Baker BJ (eds) Marine chemical ecology. CRC Press, Boca Raton, FL, p 431-462

- Harder T, Lau SCK, Dahms HU, Qian PY (2002) Isolation of bacterial metabolites as natural inducers for larval settlement in the marine polychaete Hydroides elegans (Haswell). J Chem Ecol 28:2029-2044

Harrington L (2004) Ecology of crustose coralline algae: interactions with scleractinian corals and responses to environmental conditions. PhD thesis, James Cook University, Townsville

Harrington L, Fabricius K, De'Ath G, Negri A (2004) Recognition and selection of settlement substrata determine postsettlement survival in corals. Ecology 85:3428-3437

Harrison PL, Wallace CC (1990) Reproduction, dispersal and recruitment of scleractinian corals. In: Dubinsky Z (ed) Ecosystems of the world 25: coral reefs. Elsevier, Amsterdam, p 133-207

Hay M, Pawlik J, Duffy J, Fenical W (1989) Seaweed-herbivore-predator interactions: host-plant specialization reduces predation on small herbivores. Oecologia 81: 418-427

> Heyward AJ, Negri AP (1999) Natural inducers for coral larval metamorphosis. Coral Reefs 18:273-279

> Hughes TP (1994) Catastrophes, phase-shifts, and large-scale degradation of a Caribbean coral reef. Science 265: $1547-1551$

Hughes TP, Baird AH, Dinsdale EH, Moltschaniwskyj NA,
Pratchett MS, Tanner JE, Willis BL (1999) Patterns of recruitment and abundance of corals along the Great Barrier Reef. Nature 39750-39763

> Hughes TP, Baird AH, Bellwood DR, Card M and others (2003) Climate change, human impacts, and the resilience of coral reefs. Science 301:929-933

> Hughes TP, Bellwood DR, Folke C, Steneck RS, Wilson J (2005) New paradigms for supporting the resilience of marine ecosystems. Trends Ecol Evol 20:380-386

Hughes TP, Rodrigues MJ, Bellwood DR, Ceccarelli D and others (2007) Phase shifts, herbivory, and the resilience of coral reefs to climate change. Curr Biol 17:360-365

Jensen A (1977) Chemical conditioning of seawater by algal growth and development. In: Faulkner DJ, Fenical WH (eds) Marine natural products chemistry. Plenum Press, New York, p 329-336

Jensen PR, Kauffman CA, Fenical W (1996) High recovery of culturable bacteria from the surfaces of marine algae. Mar Biol 126:1-7

> Jiang ZD, Jensen PR, Fenical W (1999) Lobophorins A and B, new anti-inflammatory macrolides produced by a tropical marine bacterium. Bioorg Med Chem Lett 9:2003-2006

> Johnson CR, Sutton DC (1994) Bacteria on the surface of crustose coralline algae induce metamorphosis of the crownof-thorns starfish Acanthaster planci. Mar Biol 120: 305-310

Johnson CR, Muir DG, Reysenbach AL (1991) Characteristic bacteria associated with surfaces of coralline algae: a hypothesis for bacterial induction of marine invertebrate larvae. Mar Ecol Prog Ser 74:281-294

Johnson CR, Lewis RE, Nichols DS, Degnan BM (1997) Bacterial induction of settlement and metamorphosis in marine invertebrates. Proc 8th Int Coral Reef Symp, Panama, p 1219-1225

Jompa J, McCook LJ (2002a) The effects of nutrients and herbivory on competition between a hard coral (Porites cylindrica) and a brown alga (Lobophora variegata). Limnol Oceanogr 47:527-534

Jompa J, McCook LJ (2002b) Effects of competition and herbivory on interactions between a hard coral and a brown alga. J Exp Mar Biol Ecol 271:25-39

Kline DI, Kuntz NM, Breitbart M, Knowlton N, Rohwer F (2006) Role of elevated organic carbon levels and microbial activity in coral mortality. Mar Ecol Prog Ser 314: 119-125

Ktari L, Guyot M (1999) A cytotoxic oxysterol from the marine alga Padina pavonica (L.) Thivy. J Appl Phycol 11:511-513

> Kuffner IB, Paul VJ (2004) Effects of the benthic cyanobacterium Lyngbya majuscula on larval recruitment of the reef corals Acropora surculosa and Pocillopora damicornis. Coral Reefs 23:455-458

> Kuffner IB, Walters LJ, Becerro MA, Paul VJ, Ritson-Williams R, Beach KS (2006) Inhibition of coral recruitment by macroalgae and cyanobacteria. Mar Ecol Prog Ser 323: $107-117$

Larkum AWD, Koch EMW, Kuhl M (2003) Diffusive boundary layers and photosynthesis of the epilithic algal community of coral reefs. Mar Biol 142:1073-1082

Littler MM, Littler DS (1997) Epizoic red alga allelopathic (?) to a Caribbean coral. Coral Reefs 16:168

> Maida M, Coll JC, Sammarco PW (1994) Shedding new light on scleractinian coral recruitment. J Exp Mar Biol Ecol 180:189-202

- Maida M, Sammarco PW, Coll JC (1995a) Effects of soft corals on scleractinian coral recruitment: I. directional allelopathy and inhibition of settlement. Mar Ecol Prog Ser 121: 191-202 
Maida M, Sammarco PW, Coll JC (1995b) Preliminary evidence for directional allelopathic effects of the soft coral Sinularia flexibilis (Alcyonacea, Octocorallia) on scleractinian coral recruitment. Bull Mar Sci 56:303-311

Maypa AP, Raymundo LJ (2004) Algae-coral interactions: mediation of coral settlement, early survival, and growth by macroalgae. Silliman J 45:76-95

McClanahan TR, McField M, Huitric M, Bergman K and others (2001) Responses of algae, corals and fish to the reduction of macroalgae in fished and unfished patch reefs of Glovers Reef Atoll, Belize. Coral Reefs 19:367-379

McConnaughey TA, Adey WH, Small AM (2000) Community and environmental influences on reef coral calcification. Limnol Oceanogr 45:1667-1671

McCook LJ (1999) Macroalgae, nutrients and phase shifts on coral reefs: scientific issues and management consequences for the Great Barrier Reef. Coral Reefs 18: 357-367

McCook LJ, Jompa J, Diaz-Pulido G (2001) Competition between corals and algae on coral reefs: a review of evidence and mechanisms. Coral Reefs 19:400-417

McCook LJ, Folke C, Hughes TP, Nystrom M, Obura D, Salm R (2007) Ecological resilience, climate change and the Great Barrier Reef: an introduction. In: Marshall P, Johnson J (eds) Climate change and the Great Barrier Reef. Great Barrier Reef Marine Park Authority, Townsville, p 75-96

Morse ANC (1991) How do planktonic larvae know where to settle? Am Sci 79:154-167

Morse ANC (1992) Role of algae in the recruitment of marine invertebrates. In: John DM, Hawkins SJ, Price JH (eds) Plant-animal interactions in the marine benthos. Clarendon Press, Oxford, p 385-404

Morse DE, Morse ANC (1991) Enzymatic characterization of the morphogen recognized by Agaricia humilis (scleractinian coral) larvae. Biol Bull (Woods Hole) 181: 104-122

Morse DE, Hooker N, Morse ANC, Jensen RA (1988) Control of larval metamorphosis and recruitment in sympatric agariciid corals. J Exp Mar Biol Ecol 116:193-217

- Morse DE, Morse ANC, Raimondi PT, Hooker N (1994) Morphogen based chemical flypaper for Agaricia humilis coral larvae. Biol Bull (Woods Hole) 186:172-181

Morse ANC, Iwao K, Baba M, Shimoike K, Hayashibara T, Omori M (1996) An ancient chemosensory mechanism brings new life to coral reefs. Biol Bull (Woods Hole) 191: $149-154$

> Negri AP, Webster NS, Hill RT, Heyward AJ (2001) Metamorphosis of broadcast spawning corals in response to bacteria isolated from crustose algae. Mar Ecol Prog Ser 223: 121-131

Nugues MM, Bak RPM (2006) Differential competitive abilities between Caribbean coral species and a brown alga: a year of experiments and a long-term perspective. Mar Ecol Prog Ser 315:75-86

Nugues MM, Szmant AM (2006) Coral settlement onto

Editorial responsibility: Charles Birkeland,

Honolulu, Hawaii, USA
Halimeda opuntia: a fatal attraction to an ephemeral substrate? Coral Reefs 25:585-591

Paul VJ, Nelson SG, Sanger HR (1990) Feeding preferences of adult and juvenile rabbitfish Siganus argenteus in relation to chemical defences of tropical seaweeds. Mar Ecol Prog Ser 60:23-34

Paul VJ, Cruz-Rivera E, Thacker RW (2001) Chemical mediation of macroalgal-herbivore interactions: ecological and evolutionary perspectives. In: McClintock JB, Baker BJ (eds) Marine chemical ecology. CRC Press, Boca Raton, FL, p 227-265

Pawlik JR (1992) Chemical ecology of the settlement of benthic marine invertebrates. Oceanogr Mar Biol Annu Rev 30:273-335

Raimondi PT, Morse ANC (2000) The consequences of complex larval behavior in a coral. Ecology 81:3193-3211

Renaud PE, Hay ME, Schmitt TM (1990) Interactions of plant stress and herbivory: intraspecific variation in the susceptibility of a palatable versus an unpalatable seaweed to sea urchin grazing. Oecologia 82:217-226

Solandt JL, Campbell AC (2001) Macroalgal feeding characteristics of the sea urchin Diadema antillarum Phillipi at Discovery Bay, Jamaica. Caribb J Sci 37:227-238

Steinberg PD, de Nys R (2002) Chemical mediation of colonization of seaweed surfaces. J Phycol 38:621-629

Steinberg PD, de Nys R, Kjelleberg S (2001) Chemical mediation of surface colonization. In: McClintock JB, Baker BJ (eds) Marine chemical ecology. CRC Press, Boca Raton, FL, p 355-387

Steinberg PD, de Nys R, Kjelleberg S (2002) Chemical cues for surface colonization. J Chem Ecol 28:1935-1951

Stern JL, Hagerman AE, Steinberg PD, Mason PK (1996) Phlorotannin-protein interactions. J Chem Ecol 22: 1877-1899

Tuya F, Martin JA, Reuss GM, Luque A (2001) Food preferences of the sea urchin Diadema antillarum in Gran Canaria (Canary Islands, central-east Atlantic Ocean). J Mar Biol Assoc UK 81:845-849

Walters LJ, Hadfield MG, Smith CM (1996) Waterborne chemical compounds in tropical macroalgae: positive and negative cues for larval settlement. Mar Biol 126:383-393

Walters LJ, Smith CM, Hadfield MG (2003) Recruitment of sessile marine invertebrates on Hawaiian macrophytes: Do pre-settlement or post-settlement processes keep plants free from fouling? Bull Mar Sci 72:813-839

Webster NS, Smith LD, Heyward AJ, Watts JEM, Webb RI, Blackall LL, Negri AP (2004) Metamorphosis of a scleractinian coral in response to microbial biofilms. Appl Environ Microbiol 70:1213-1221

Willis BL, Babcock RC, Harrison PL, Wallace CC (1997) Experimental hybridization and breeding incompatibilities within the mating systems of mass spawning reef corals. Coral Reefs 16:S53-S65

Wylie CR, Paul VJ (1988) Feeding preferences of the surgeonfish Zebrasoma flavescens in relation to chemical defences of tropical algae. Mar Ecol Prog Ser 45:23-32

Submitted: November 26, 2007; Accepted: March 3, 2008

Proofs received from author(s): June 18, 2008 